\title{
Implementation of Quantum Teaching Model on Improving Physics Learning Outcomes In The Cognitive Domain At Junior High School
}

\author{
Suritno Fayanto ${ }^{1}$, Musria ${ }^{2}$, Erniwati ${ }^{3}$, Luh Sukariaih ${ }^{4}$, Hunaidah $^{5}$ \\ ${ }^{1}$ Departmen of Master in Physics Education, University of Ahmad Dahlan, Indonesia \\ 2,3,4,5 Department of Physics Education, University of Halu Oleo, Indonesia \\ Coressponding Author. E-mail: \\ 1. Suritno1707041005@webmail.uad.ac.id
}

Received: 24 Juni 2019

Accepted: 28 Juli 2019

Online Published: 30 Juli 2019

\begin{abstract}
Teaching physics must present as attractive as possible students can identify, search, and formulate problems, and able to solve issues in detail. This study aims to describe the improvement of learning outcomes in physics-cognitive realm using quantum teaching model. The location of the study place at junior high school 1 Lohia, Muna Regency, Indonesia. The study sample consisted of 22 students of junior high school class $\mathrm{VIII}_{2}$ studied through a quantum teaching model, and $22 \mathrm{VIII}_{3}$ junior high school students learned conventional learning models from a population of 88 people. The subject matter used to wave and vibration. This type of research classroom experiment research using a pretest-posttest control group design. Data collection techniques used tests of cognitive learning outcomes of students in the form of multiple choices. The analysis technique uses descriptive and inferential analysis. The final results conclude the average value of the final test of students on the learning outcomes of the learning knowledge of students through the quantum teaching model is higher than the average value of the final test of students learn through conventional learning models based on a significance value of 0.029
\end{abstract}

Keywords: Quantum Teaching; Learning Outcomes; Cognitive; Teaching Learning

How to cite this article :

Fayanto, S., Musria, M., Erniwati, E., Sukariasih, L., \& Hunaidah, H. (2019). Implementation of Quantum Teaching Model On Improving Physics Learning Outcomes In The Cognitive Domain At Junior High School. IJIS Edu : Indonesian Journal of Integrated Science Education, 1(2). doi:http://dx.doi.org/10.29300/ijisedu.v1i2.1958 


\section{INTRODUCTION}

The facts the field show that Science-Physics still taught through learning originating from one book or only theoretically, science-physics education seems only as a cognitive transfer process from the teacher's mind into the minds of students (Bektiarso, 2000). Science-Physics Learning must indicate as being oriented or student-centered. It is because the topic of sciencephysics requires practical work directly or conducting experiments that need to be known by students, that in science-physics learning students will be more active in following the teaching and learning process (Mardika, 2003).

The condition that occurs in junior high school 1 Lohia learning model used still with conventional learning, and the learning device used refers to the KTSP curriculum. Martinis Yamin (2007) revealed that the learning process studentcentered, student-directed to learn independently and work together. The process of science-physics learning at secondary school, in fact, still dominated by teachers compared to students (Hunaidah \& Fayanto, 2018). Almost all activities are only teacher-centered (Fayanto et al., 2019). In the learning process, students only receive lessons taught the teacher so that there only one-way communication, namely teachers to students without their experimental activities (Fatmawati et al., 2019). Even the school laboratory facilities that can be used to conduct experiments and the tools to be used in this experiment are easy to obtain. It is learning systems such as to cause students not accustomed to practicing their efforts to discover facts, concepts, and theories through the observation of tangible objects. Kusuma \& Kusuma (2018) argues that one of the successes learning process depends on the skills and abilities of the teacher in stimulating students in learning. Therefore, in physics teaching the teacher must plan the strategies and methods of learning that used following the character of the students and the character of the physics material that students are more comfortable with the concept of physics (Karmila, Mahardik, \& Gani, 2017).

Based the interview results obtained information from one teacher of the Grade VIII Science-Physics subject when the initial observations conducted researchers on October 31, 2017, at junior high school 1 Lohia found that some students in class VIII scored lower than the minimum completeness criteria which applied in schools namely 68 . Therefore need for learning that involves all students' ability to search, discover, and investigate systematically, logically, and critically and do not require a relatively long time.
It is based on existing conditions, offering a learning model to improve student learning outcomes that allow students to make observations and explorations to build their understanding. One model of learning that can apply to train increases cognitive learning outcomes of students is a model of quantum. Quantum Teaching is a learning model that invites students to play an active role in learning and to use the knowledge base of the students to develop their knowledge and acquire new knowledge (Ulandari \& Surya, 2017). Quantum learning brings together various things to create more meaningful information using all the neural networks found in the brain. Quantum learning aims to realize the individual as a whole, moving from the findings and assumptions of quantum physics (Zeybek, 2017). The quantum teaching-learning model can be seen as an ideal learning model because it emphasizes collaboration between students and teachers to achieve common goals (Sholikhah, 2017). The purpose of principle shows that the first step that is taken by a teacher in starting the learning process to enter the world of students, how to connect the subject matter to be provided with events that occur in their real life (Silfia, Irwan, \& Yerizon, 2019). Susanto (2016) in a research report that the model of quantum positive effect on improving student learning outcomes. This expression enhanced by Pratiwi (2005) in a study that states the model of quantum better than learning model STAD Cooperative in improving student achievement in energy materials in junior high school Muhammadiyah 6 Surabaya while Solikin \& Abdullah (2014) reported that the quantum teaching model of student response very good for improving learning outcomes.

Based on the description that researchers are interested in reviewing the application of the quantum teaching model to improve physics learning outcomes in the cognitive domain, especially at junior high school 1 Lohia. The aim of the study to compare the teaching of quantum teaching models with conventional models in physics learning at school. The benefits of this research aimed at physics subject teachers that quantum teaching models can apply as an alternative learning model that can apply in schools

\section{METHODS}

\section{Sample and Population}

Participants in the study consisted of VIII2 and VIII3 grade students of junior high school 1 Lohia and enrolled in the second semester of the academic year 2016/2017. Participants in this study obtained by random sampling through the results of the analysis of learning outcomes previous 
semester. Determines the experimental class and control class done with the drawing process, to obtain VIII2 grade by the number of students 22 people as an experimental class and class VIII3 by the number of students 22 people as the control class.

\section{Research Design}

In this study used a randomized control group design pretest-posttest. This design is a simple design that gets one treatment and control (Sugiyono, 2015).

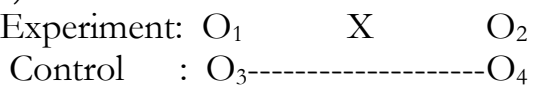

Where,

$\mathrm{O}_{1}$ and $\mathrm{O}_{3}=$ The initial test carried out in the experimental class and the control class

$\mathrm{O}_{2}$ and $\mathrm{O}_{4}=$ The final test carried out in the experimental class and the control class

$\mathrm{X}=$ The experimental class given treatment in learning with quantum teaching models and the control class not treated

--- $=$ Treatment of conventional models.

\section{Research Procedures}

The steps of this research described as follows: (a) Conducting initial observations at junior high school 1 Lohia to find out the state of the school, the population to be used as research objects, student cognitive domain learning outcomes, laboratory conditions, determine samples, and applied learning models in the learning process, (b) Preparing learning devices form of syllabus, learning program plans and student worksheets in accordance with quantum teaching models and conventional learning models, (c) Creating test instrument grids, (d) Developing test instruments based on networks which compiled, (e) Analyzing the results of the test instruments in the trial class to determine the question validity and reliability of the questions, ( $f$ ) Determining the test questions that will be used in the final test in the experimental class and the control class that meets the requirements, $(\mathrm{g})$ Carrying out the initial test in the control class and experimental class, (h) Implementing the quantum teaching model in the experimental class and carry out conventional learning models in the control class, (i) Conduct final tests on the experimental class and control class, (j) Analyze the results of the initial test and the final test.

\section{Research Instrument and Technique Analysis}

The research instruments consisted of the syllabus, learning program plans and student worksheets, and cognitive learning outcomes test instruments. To find out the validity of the feeding test instrument, it analyzed item analysis, test reliability, distinguishing tests, the level of difficulty of the items. For data analysis techniques using descriptive analysis consisting of determining the mean, standard deviation, variance, determining the maximum and minimum values, to analyze the significance of learning outcomes between pre-test and post-test using the $\mathrm{N}$-gain test. While inferential analysis consists of a normality test, homogeneity test, and T-test. Data analysis techniques assisted with SPSS 16.0 and Microsoft Excel software.

\section{Research Hypothesis}

Hypothesis testing using independent sample T-test using SPSS software. Test criteria: If the value or significant value is 0.05 , then $\mathrm{H}_{0}$ rejected or $\mathrm{H}_{1}$ accepted. The following research hypothesis.

1) First hypothesis

$\mathrm{H}_{0}: \mu_{1}=\mu_{2}$

$\mathrm{H}_{1}: \mu_{1} \neq \mu_{2}$

Where,

$\mathrm{H}_{0}$ : There was no difference between the mean scores of the students' initial tests in the experimental class and the mean scores of the initial test results of the control class students.

$\mathrm{H}_{1}$ : There is a significant difference within the mean scores of the students 'initial tests in the experimental class and the mean scores of the students' initial test

$\mu_{1}$ : The initial test average score in the experimental class students

$\mu_{2}$ : The initial test average score in the control class students

2) Second hypothesis

$\mathrm{H}_{0}: \mu_{1} \leq \mu_{2}$

$\mathrm{H}_{1}: \mu_{1} \geq \mu_{2}$

Where,

$\mathrm{H}_{0}$ : The final test scores of students in the experimental class are lower or equal to the final test average of the control class students

$\mathrm{H}_{1}$ : The average value of the student's final test on experimental class is higher than the average of the final test control class

$\mu_{1}$ : The average final test score of the experimental class students control class

$\mu_{2}$ : The average value of the final test

3) Third hypothesis

$\mathrm{H}_{0}: \mu_{\mathrm{g} 1} \leq \mu_{\mathrm{g} 2}$
$\mathrm{H}_{1}: \mu_{\mathrm{g} 1} \geq \mu_{\mathrm{g} 2}$
Where,

$\mathrm{H}_{0}$ : The average $\mathrm{N}$-gain value of students in the experimental class is lower or equal to the average gain of students in the control class 
$\mathrm{H}_{1}$ : The average $\mathrm{N}$-gain value in the experimental class students is higher than the average $\mathrm{N}$ gain value of the control class students

$\mu_{\mathrm{g} 1}$ : The average value of the $\mathrm{N}$-gain experimental class students

$\mu_{\mathrm{g} 2}$ : The average $\mathrm{N}$-gain value of the control class students

\section{RESULT AND DISCUSSION}

Result

Table 1. The results of the analysis of initial and final tests of student learning outcomes on topic waves and vibration the experimental class and control class

\begin{tabular}{llcccccc}
\hline \multirow{2}{*}{ No } & \multirow{2}{*}{ Value } & \multicolumn{2}{c}{ Experiment class } & \multicolumn{2}{c}{ Control class } & \multicolumn{2}{c}{ N-gain value } \\
\cline { 3 - 8 } & & $\begin{array}{c}\text { Initial } \\
\text { test }\end{array}$ & $\begin{array}{c}\text { Final } \\
\text { test }\end{array}$ & $\begin{array}{c}\text { Initial } \\
\text { test }\end{array}$ & $\begin{array}{c}\text { Final } \\
\text { test }\end{array}$ & $\begin{array}{c}\text { Initial } \\
\text { test }\end{array}$ & Final test \\
\hline 1 & Minimum & 15 & 70 & 10 & 70 & 0,1 & 0,4 \\
2 & Maximum & 50 & 100 & 55 & 90 & 1 & 0,48 \\
3 & Mean & 33,86 & 82,05 & 32,72 & 77,27 & 0,72 & 0,65 \\
4 & Deviation standar & 12,81 & 7,18 & 13,69 & 9,85 & 0,12 & 0,12 \\
\hline
\end{tabular}

Based on Table 1 seen that the average value of student learning outcomes in the topic of vibration and wave for the experimental class and the control class increased categorizing the value of student learning outcomes topic of vibration and wave of
The analysis of this experimental study used the help of Microsoft Excel in determining descriptive analysis and SPSS 16.0 software which included test prerequisites for analysis and hypothesis testing

\section{Results Descriptive Analysis of Student} Learning Outcomes Cognitive Domains

Descriptive analysis, initial test, and final test experimental classes and control classes presented in Table 1. experimental class and control class as presented in between the control class and the experimental class imaged in Figure 1 Table 2 and Table 3. More clearly, the difference

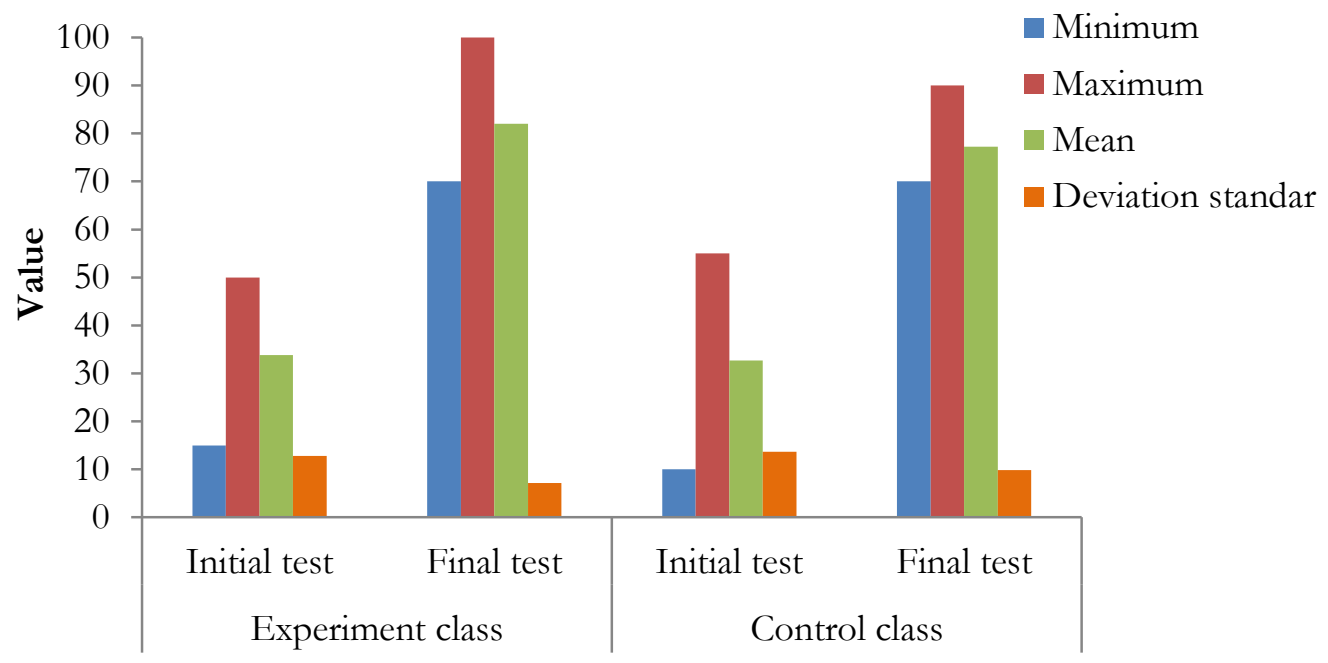

. Figure 1. Differences in the value of learning outcomes between two classes

Figure 1 provides information about the difference between learning outcomes and experimental class. In the experimental class, the posttest value (final test score) higher than the posttest value (final test value) in the control class (Table 1). Whereas for the presets value between the control class and the experimental class did not show a significant 
Table 2. Categorizing the initial test value of learning outcomes experimental and control class

\begin{tabular}{cccc}
\hline \multirow{2}{*}{ Value interval } & \multirow{2}{*}{ Category } & \multicolumn{2}{c}{ Student cognitive learning outcomes } \\
\cline { 3 - 4 } & & Experiment class & Control class \\
\hline$X_{i}>+13,12$ & High & 3 Pupil & 3 Pupil \\
$33,30-13,12 \leq X_{i} \leq+13,12$ & Medium & 12 Pupil & 14 Pupil \\
$X_{i}<-13,12$ & Low & 7 Pupil & 5 o Pupil \\
\hline
\end{tabular}

Table 3. Categorizing the final test value of learning outcomes experimental and control class

\begin{tabular}{cccc}
\hline Value interval & \multirow{2}{*}{ Category } & \multicolumn{2}{c}{ Student cognitive learning outcomes } \\
\cline { 3 - 4 } & & Experiment class & Control class \\
\hline$X_{i}>+7,35$ & High & 4 Pupil & 2 Pupil \\
$79,66-7,35 \leq X_{i} \leq+7,3$ & Medium & 16 Pupil & 13 Pupil \\
$X_{i}<-7,35$ & Low & 2 Pupil & 7 Pupil \\
\hline
\end{tabular}

Table 4 interprets the N-Gain category of student learning outcomes in the topic of vibration and wave, both experimental class and control class students are mostly in the moderate category, namely nine people $(40.91 \%)$ the experimental class and $14(63,64 \%)$ the control class.

\section{Normality Test}

The normality test used to find whether the learning outcomes of the two classes of students normally distributed or not using normality test statistics using the Kolmogorov-Smirnov formula. The results of the calculations presented in Table 5

Table 5. Results of data normality test learning outcomes of students experimental and control class

\begin{tabular}{|c|c|c|c|c|c|}
\hline \multirow{2}{*}{ Class } & \multirow{2}{*}{ Test } & \multicolumn{2}{|c|}{ Kolmogorov-Smirnov } & \multirow{2}{*}{$a$} & \multirow{2}{*}{ Information } \\
\hline & & Statistic & Sig. & & \\
\hline \multirow{2}{*}{ Experiment } & Initial test & 0,184 & 0,051 & \multirow{4}{*}{0,05} & \multirow{4}{*}{$\begin{array}{c}\text { Normal } \\
\text { distribution of } \\
\text { data }\end{array}$} \\
\hline & Final test & 0,160 & 0,150 & & \\
\hline \multirow{2}{*}{ Control } & Initial test & 0,157 & 0,169 & & \\
\hline & Final test & 0,191 & 0,070 & & \\
\hline
\end{tabular}

Table 5 can explain Sig. The experimental class and the control class $>0.05$ so that H0 accepted, concluded that the distribution of learning outcomes data of students normally distributed.

\section{Homogeneity Test}

The test results of the homogeneity of cognitive learning outcomes of students learn through quantum teaching models, and conventional learning models can view in Table 6.

Table 6. The result of homogeneity test results learners experimental class and control class

\begin{tabular}{ccccccc}
\hline Test & Levana statistic & df1 & df2 & sign & $\boldsymbol{a}$ & Information \\
\hline Initial & 0,000 & 1 & 42 & 0,991 & \multirow{2}{*}{0,05} & \multirow{2}{*}{ Homogenous Data } \\
Final & 0,027 & 1 & 42 & 0,871 & & \\
\hline
\end{tabular}

Table 6 shows the Sig. The experimental and the control class $>0.05$ that $\mathrm{HO}$ is accepted; it can conclude that the distribution of data on student learning outcomes is homogeneous.

\section{Hypothesis Test \\ First hypothesis}

The results of different test scores of the average initial test of students learn through quantum teaching models and conventional learning models more fully presented in Table 7.

Table 7. The results of the initial T-test were students of the experimental and the control class

\begin{tabular}{lllllll}
\hline \multicolumn{1}{c}{ Class } & $\mathbf{N}$ & Sig. & $\boldsymbol{a}$ & $\mathbf{t}_{\text {count }}$ & $\mathbf{t}_{\text {table }}$ & Information \\
\cline { 1 - 5 } Experiment & 22 & \multirow{2}{*}{0,82} & $\begin{array}{c}0,0 \\
5\end{array}$ & 0,22 & 2,01 & \multirow{2}{*}{$\mathrm{H}_{\mathrm{o}}$ Accept } \\
\hline Control & 22 & & 5 & & & \\
\hline
\end{tabular}

Note, $\mathrm{N}=$ Total sample. 
Based on Table 7 seen that the Sig. greater than $=0.05$, it can be concluded that there is no significant difference between the average value of the initial test of students learn through quantum teaching models and conventional learning models at $\alpha=0.05$

Table 8. Final T-test results of experimental and control class students

\section{Second hypothesis}

The results of different test scores for the standard final test of students learn through quantum teaching models, and conventional learning models presented in Table 8 at $\alpha=0.05$.

\begin{tabular}{lcccccc}
\hline \multicolumn{1}{c}{ Class } & $\mathbf{N}$ & Sig. $(\varrho)$ & $\boldsymbol{a}$ & $\mathbf{t}_{\text {Count }}$ & $\mathbf{t}_{\text {table }}$ & Information \\
\hline $\begin{array}{l}\text { Experiment } \\
\text { Control }\end{array}$ & 22 & 0,029 & 0,05 & 2,25 & 2,01 & \multirow{2}{*}{$\mathrm{H}_{\mathrm{o}}$ Reject } \\
\hline
\end{tabular}

Note, $\mathrm{N}=$ Total sample.

Based on Table 8 seen the Sig. Smaller than $=0.05$, concluded that the average value of the final test of students learns through the quantum teaching model higher than the average value of the final test of students learn through conventional learning model.

Table 9. The T-test results in the $\mathrm{N}$-gain value of the experimental and the control class

\section{Third hypothesis}

The results of the $\mathrm{N}$-gain test of students learn through quantum teaching models and conventional learning models fully presented in Table 9.

\begin{tabular}{ccccccc}
\hline Class & $\mathbf{N}$ & Sig. $(\varrho)$ & $\boldsymbol{a}$ & $\mathbf{t}_{\text {count }}$ & $\mathbf{t}_{\text {table }}$ & Information \\
\hline $\begin{array}{c}\text { Experiment } \\
\text { Control }\end{array}$ & 22 & 0,041 & 0,05 & 2,11 & 2,01 & $\mathrm{H}_{\mathrm{o}}$ Reject \\
\hline
\end{tabular}

Note, $\mathrm{N}=$ Total sample.

Based on Table 9, seen the Sig. Smaller than $=0.05$, concluded that the average value of the $\mathrm{N}$ gain of students taught through the quantum teaching model significantly higher than the average $\mathrm{N}$-gain value of students taught through conventional learning models.

\section{DISCUSSION}

Final test results obtained students in each class, based on the results of the descriptive statistical analysis the average value of students increased, both the experimental and control class, where the average value of the experimental class of 82.05 with a standard deviation of 7.18 and an average value control class is 77.27 with a standard deviation of 6.85 . Both of these results indicate that there is an increase in student learning outcomes in each class after the learning process. It is because the students have learned and obtain information about the topic of vibrations and waves. However, when compared between the average value of the final test results obtained by experimental class students and the control class, the increase learning outcomes in the experimental class was higher than the control class.

Based the results of hypothesis testing obtained, that statistically the average value of the final test of students in the class taught through the quantum teaching model is significantly better than the average value of the final test of students taught through conventional learning models. It is because in the experimental class using quantum teaching students are more active in learning and the knowledge gained is more comprehensive and meaningful in the integration of material concepts compared the control class which only gets information from the teacher and education that still separate. Mawardi, Hidayat, \& Nursalam (2017) In the study explained that using the quantum teaching model can increase interest in learning. In this supported the results of the analysis there was an increase in learning outcomes between the control class and the experimental class because one of the advocates was students' interest in learning (see Table 1).

The results of studying the realm of knowledge of students the experimental class are better because of the application of quantum models that facilitate teachers to serve students in learning and delivering course material (Table 1). In addition, by applying the concept of quantum, i.e., with a friendly attitude of teachers and learners understand the circumstances that make learners feel comfortable in the learning process, that students quickly grasp the concept of the material studied. Kusno \& Purwanto (2011) said that quantum learning could make students active and thus reduce the dominance of teachers and students actively seek and build independently the knowledge that they acquire.

In addition, the role of teachers delivers material linking learners' daily lives, that learners 
more quickly and easily understand what is presented by the teacher. As reported by Khairunnisa, Miaz, \& Karneli (2018) principles of quantum teaching students is bringing the world to our world, and put our world into their world. It shows that in the learning activities of students need to open up the scheme to then be delivered to the subject matter. In addition, quantum teaching also has creative ideas at each stage of the quantum teaching model, such as the use of teaching aids that make students interested and like what they learn (Sujatmika, Hasanah, \& Hakim, 2018). If teachers convey the subject matter favored learners, each learner will be severe in studying it. Then the reward for the hard work done every learner is one factor for the competent learners in learning his fellow vibrations and waves, which in turn will get better results.

This study, the quantum teaching model the experimental class of students directed at collaborating with their learning groups, fostering the interest of students to explore information that they did not know beforehand that students were able to motivate themselves because of their curiosity in themselves. The makes the learning outcomes of the experimental class knowledge higher than the control class. This argument strengthened from the results of research (Arifin, Lesmono, \& Sudarti, 2016; Damanik, 2017) which state that the quantum teaching model can improve student learning outcomes and have a significant favorable influence on the learning outcomes and scientific attitudes of students. Other than that (Gunarhadi, Kassim, \& Shaari, 2014; Kusuma \& Kusuma, 2018) argued that quantum learning strategies have a better impact on student learning achievement in school.

So that the quantum teaching model suitable to be applied to the learning activities of physics in schools because of the research conducted provides differences in learning outcomes in the realm of knowledge of students with conventional learning models. This activity shows that teaching with the quantum teaching model can improve learning outcomes in the knowledge domain of class VIII students of Junior High School 1 Lohia.

\section{CONCLUSION}

Based on the results of the study, it can conclude that the cognitive learning outcomes of students taught by quantum teaching are higher than conventional teaching models in learning topic of vibration and wave physics for class VIII students. The makes the quantum teaching model can employ as one of the models applied in physics learning in junior high school.

\section{ACKNOWLEDGMENT}

Gratitude to the Head of the Junior High School 1 Lohia has allowed researchers and facilitate researchers so that research can resolve.

\section{REFERENCES}

Arifin, Z., Lesmono, A. D., \& Sudarti. (2016). Pengaruh Model Quantum Learning Disertai Metode Eksperimen Terhadap Hasil Belajar Fisika. Jurnal Pembelajaran Fisika, 4(4), 365-370.

Bektiarso, S. (2000). Pentingnya Konsepsi Awal dalam Pembelajaran Fisika. Jurnal Saintifika, 1(1), 11-20.

Damanik, D. P. (2017). Pengaruh Model Quantum Teaching Terhadap Hasil Belajar Siswa Pada Materi Pokok Listrik Dinamis. Jurnal Penelitian Bidang Pendidikan, 23(2), 112-117.

Fatmawati, Fayanto, S., Sukariasih, L., \& Heri Retnawati. (2019). Investigating the Effectiveness of Inquiry Learning and Direct Learning Models toward Physics Learning. Advances in Social Science, Education and Humanities Research, 317(IConProCS), $260-265$

Fayanto, S., Sulisworo, D., Fathan, H., \& Istiqomah, N. (2019). The Implementation of Multimedia on Physics Learning Based on Direct Instruction Model in The Topic of Light. Indonesia Journal of Learning Education and Counseling, 1(2), 124-132.

Gunarhadi, Kassim, M., \& Shaari, A. S. (2014). Strategy on Student Academic Achievements and Self- Esteem in Inclusive Schools. Malaysian Journal of Learning and Instruction, 11, 191-205.

Hunaidah, M., \& Fayanto, S. (2018). Penerapan model pembelajaran Predict-ObserveExplain (POE) dengan metode demonstrasi untuk meningkatkan aktivitas dan hasil belajar IPA Fisika materi pokok kalor Kelas $\mathrm{VII}_{2}$ SMP Negeri 15 Kendari. Seminar Nasional Quantum (Vol. 25, pp. 293-298). Yogyakarta: Universitas Ahmad Dahlan.

Karmila, N., Mahardik, I. K., \& Gani, A. A. (2017). Increased of VVPR Through Quantum Teaching Model With Student Worksheet Based on Multiple Representation. Pancaran Pendidikan, 6(3), 54-60. 
https://doi.org/10.25037/pancar an.v6 i2.49

Khairunnisa, Miaz, Y., \& Karneli, Y. (2018). The effect of quantum teaching on students' motivation on social studies (An quasiexperiment for 5th-grade elementary school). Proce-International Conferences on Educational, Social Sciences and Technology, 1, 151-156.

Kusno \& Purwanto, J. (2011). Effectiveness of Quantum Learning for Teaching Linear Program at the Muhammadiyah Senior High School of Purwokerto in Central Java, Indonesia. International Journal for Educational Studies, 4(1), 83-92.

Kusuma, E. D., \& Kusuma, R. Y. (2018). The Development of Problem-Based Quantum Learning Model in Elementary School. International Journal of Educational Research Review, 3(3), 9-16.

Mardika. (2003). Peningkatan Prestasi Matematika Siswa Melalui Model Quantum Teaching Melibatkan Multi Intellegence. Retrieved June 16, 2019, from sofia.edriati@yahoo.co.id

Martinis Yamin. (2007). Profesionalisasi Guru dan Implementasi KTSP (1st ed.). Jakarta: Gaung Persada Press.

Mawardi, S., Hidayat, M. Y., \& Nursalam. (2017). Efektivitas Model Pembelajaran Quantum Teaching dengan Teknik APA Manfaat Bagiku Terhadap Minat Belajar Fisika Peserta Didik. Jurnal Pendidikan Fisika UIN-Alauddin, 5(2), 128-133.

Pratiwi, I. (2005). Perbandingan Pembelajaran Kuantum (Quantum Teaching) dengan Model Kembelajaran Kooperatif tipe STAD dalam meningkatkan prestasi belajar siswa pada materi energi di SMP
Mubammadivah 6 Surabaya. Universitas Negeri Surabaya.

Sholikhah, O. H. (2017). Implementation of Quantum Teaching Learning Viewed From Multiple Intelligences in Mathematics Learning. Proce-International Seminar of Primary Education, 1, 1-8.

Silfia, R., Irwan, \& Yerizon. (2019). Based on Quantum Teaching Model to Improve Vocational School. International Journal of Progressive Sciences and Technologies (IJPSAT), 13(1), 74-80.

Solikin, M., \& Abdullah, A. A. (2014). Pengaruh Quantum Teaching Terhadap Hasil Belajar Siswa. Jurnal Inovasi Pendidikan Fisika, 3(2), 10-13.

Sugiyono. (2015). Metode Penelitian Kuantitaf, Kualitatif dan R\&D. Bandung: Alfabeta.

Sujatmika, S., Hasanah, D., \& L L Hakim. (2018). Effect of Quantum Learning Model in Improving Creativity and Memory Effect. IOP Publishing-International Conference on Science Education, 012036(1006), 1-6.

Susanto, M. A. R. (2016). Penggunaan Model Quantum Teaching uMeningkatkan Hasil Belajar Siswa pada Mata PelajaranIP A Kelas IV SD Negeri Sinduadi 1 Kecamatan Mlati Kabupaten Sleman. Universitas Negeri Yogyakarta.

Ulandari, L., \& Surya, E. (2017). Improving Learning Outcomes of Linear Program with Quantum Teaching Model at Grade X Students SMK-BM PAB 3 Medan Estate. International Journal of Sciences: Basic and Applied Research (IJSBAR), 33(3), 120-129.

Zeybek, G. (2017). An Investigation on Quantum Learning Model. International Journal of Modern Education Studies, 1(1), 16-27. 